\title{
Resenha: "The study of macro and micro implementation of social policy", de Paul Berman
}

Informações editoriais:

Autor: Paul Bierman

Editora: RAND Corporation

Cidade: Santa Monica

Ano: 1978

ISBN: Não há, Policy Paper.

\section{Isabela Fagundes Cagnin}

Universidade Estadual de Campinas (UNICAMP)

E-mail: isabelafagundes@yahoo.com.br

O estudo sobre a implementação de políticas públicas é um campo ainda em desenvolvimento. A consideração e importância dessa etapa no ciclo das políticas públicas, assim como, o seu impacto no desempenho e resultado foi levada em consideração recentemente. Os primeiros trabalhos sobre essa etapa surgiram nos anos de 1960 e 1970 nos Estados Unidos, momento no qual a implementação deixa de ser concebida como apenas a execução das decisões tomadas nas etapas anteriores. (HAWLETT et al, 2013)

Contudo, por mais que já se tenha passado cinco décadas de estudos sobre a implementação, há ainda a carência de uma estrutura conceitual capaz de criar generalização nas observações e contribuir para com a melhora do desempenho da política. Neste sentido o autor Paul Berman, no artigo $O$ estudo macro e micro da implementação nas políticas sociais, contribui com a construção de uma estrutura conceitual baseada na interação entre a política pública e a configuração institucional, levando em consideração o plano macro - os setores de políticas públicas no contexto do federalismo - e um plano micro - a organização local.

Em suma, o autor chama a atenção para a relação entre a máquina governamental e os resultados alcançados pelas políticas, buscando além da criação de uma estrutura conceitual e de definições, a classificação dos problemas na implementação decorrentes da configuração 
institucional. Ao propor essa abordagem para a análise da implementação a compreensão do autor sobre os processos ou fases de análise das políticas públicas, deixa de ser compreendida como apenas a execução das decisões, e cede lugar para uma compreensão de que os resultados e as inovações ocorrem de forma mais inesperada.

Dessa forma, a maneira pela qual o projeto foi ou será implementado explica a variação de resultados. A implementação depende de um complexo de variáveis interdependentes que vão desde as escolhas no processo de formulação, a configuração institucional da política até a configuração da organização local que irá implementar. Ou seja, de aspectos macro e micro da implementação.

Os aspectos macro da implementação Bierman entende como uma relação vertical dos setores de políticas públicas (educação, saúde, etc.) desde o nível federal até o nível local, que abrangem portanto, as configurações institucionais dos setores e as relações setoriais. Como podemos citar, por exemplo, o caso das burocracias de um determinado setor - no Brasil, temos a burocracia da União, estadual e a municipal.

Em cada um desses setores há regras de operacionalização, conduta, rotina de procedimentos, estabilidade e etc., que são compreendidos pelo autor como padrões de enrijecimento do comportamento setorial, denominado de macro estrutura. Para Bierman a macro implementação é resultado de uma coordenação federativa entre os diversos setores ao longo dos níveis de governo, que se caracteriza como de um acoplamento frouxo, ou seja, cada setor possui seus problemas, perspectivas, propostas, estrutura, cultura particular e autonomia, mas agem e estão ligadas de forma coordenada "frouxa".

Essa relação coordenada e de acoplamento frouxo pode ser visto nos quatro fatores, que o autor destaca como distinguíveis na macro implementação, que são:

a) Administrativa: formulação de políticas de acordo com um programa do governo federal;

b) Adoção: política dos setores do governo federal passa a ser adotada nos projetos locais de governo;

c) Micro Implementação: projeto local conduz a uma prática implementadora;

d) Validade Técnica: a prática implementadora conduz a um resultado.

Revista Brasileira de Políticas Públicas e Internacionais, v.2, n.2, Dezembro/2017, pp. 176-180. 
A análise da macro implementação pode ser focalizada em um desses quatro fatores ou em todos os quatro, como por exemplo, a análise da ambiguidade de intenção na legislação de políticas públicas, análise das características organizativas dos setores no nível federal buscando melhor compreender como o programa de governo resulta em determinadas políticas, são algumas das possibilidades dessa análise.

Em seguida o autor destaca a análise da micro implementação, que de forma resumida pode ser compreendida como uma análise da implementação no nível local. O destaque é dado para os setores ou organizações locais, suas ações cotidianas e as tomadas de decisões para com a implementação e execução da política. O autor frisa que a execução fiel de uma política pública, formulada por outro nível de governo, requer mudanças nos procedimentos cotidianos da organização local o que irá refletir no resultado final da política.

Contudo, essas mudanças por vezes, não ocorrem buscando a execução fiel da política. Isso porque, algumas mudanças necessárias exigem modificações que são custosas para a organização, além disso, podem ocorrer adaptações das ações cotidianas por parte dos atores das organizações como efeito das mudanças necessárias para execução da política. Assim, o autor destaca, que tanto a política como a organização sofrem mudanças na interação um com o outro; interação essa que irá se refletir no resultado final da política em um determinado local, e nos variados resultados encontrados nos mais diferentes locais.

Dessa forma, na perspectiva federal a micro implementação começa quando há mudanças e adaptações das organizações locais, já na perspectiva local, a micro implementação é a sua execução mediante as características locais. Por isso, para a análise da micro implementação, é importante primeiro compreender a dinâmica da organização na qual a política será executada, destacando que cada organização tem sua dinâmica característica.

Como exemplo são as características locais - condição social, econômica, etc - do ambiente que refletem na organização local e na forma como provém o serviço - público e/ou privado, como também na interação entre os atores da organização e o público receptor do serviço. Neste sentido a interação é feita por uso de técnicas, seleção e combinação de ações, que resulta em uma

Revista Brasileira de Políticas Públicas e Internacionais, v.2, n.2, Dezembro/2017, pp. 176-180. 
impossibilidade de assumir que a implementação ocorrerá de forma uniforme em todos os níveis locais de governo.

As modificações oriundas da micro implementação são constituídas de três fases: a fase de mobilização, a fase do “deliverer implementation” e a fase da institucionalização. Na fase da mobilização a organização local decide sobre a política e a sua execução. A execução é realizada pelos “deliverers” por meio das operações, técnicas, ações e adaptações da organização, sendo que essas (operações, técnicas e principalmente ações e adaptações) irão definir a institucionalização ou não da rotina dos procedimentos e, portanto, da política.

Importante destacar que os “deliverer implementation” são os burocratas de linha frente que mais tarde, em 1980 será destaque nos estudos de Lipsky, no qual a trará para a análise da implementação de políticas públicas um peso muito grande para a compreensão da interferência desses atores na política e, portanto, no resultado alcançado.

Neste trabalho - The study of macro and micro implentation of social policy - o autor Paul Bierman destacou as possíveis propostas de análise da implementação levando em consideração aspectos importantes que refletem no alcance dos objetivos da política pública, como o federalismo, as relações e coordenação entre os setores de políticas, o nível local de implementação da política e o setor local de execução com suas técnicas, operações e ações cotidianas.

Apesar do trabalho do autor ser do ano de 1978, a proposta de análise que traz perspectivas macro e micro de implementação ainda é relevante para os pesquisadores, principalmente por levar em consideração relações coordenadas entre os setores e níveis de governo, a adaptação (ou não adaptação) e incorporação de novas dinâmicas pelas organizações (ou setores) locais para a execução das políticas, elementos estes importantes para as discussões de políticas intersetoriais, de rede, transversais, além de outros modelos que saem modelo majoritário setorial.

\section{Referências:}

Berman, P (1978). The study of macro and micro implementation of social policy. RAND Corporation, Santa Monica. Policy Paper.

Revista Brasileira de Políticas Públicas e Internacionais, v.2, n.2, Dezembro/2017, pp. 176-180. 
Hawlett, M.; Ramesh, M.; Perl, A (2013). Políticas Públicas. Seus ciclos e subsistemas: Uma abordagem integral. São Paulo : Elsevier.

Lipsky, M (1980). Street-level bureaucracy: dilemmas of the individual in public services. Nova York: Russel Sage Foundation.

Revista Brasileira de Políticas Públicas e Internacionais, v.2, n.2, Dezembro/2017, pp. 176-180. 